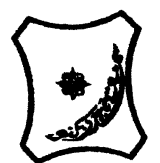

Bayero Journal of Pure and Applied Sciences, 8(2): 138 - 144

Received: September, 2015

Accepted: December, 2015

ISSN $2006-6996$

\title{
STUDIES OF ACTION OF HEAVY METALS ON CAFFEINE DEGRADATION BY IMMOBILISED LEIFSONIA SP. STRAIN SIU
}

Ibrahim, S., Muhamma, A., Tanko, A.S., Abubakar, A., Ibrahim, H., Shukor, M.Y., and Salihu Ibrahim ${ }^{*}$, Abdullahi Muhammad ${ }^{1}$, Abubakar Sadiq Tanko ${ }^{2}$, Abdussamad Abubakar ${ }^{3}$, Hadiza Ibrahim ${ }^{4}$, Mohammed Yunus Shukor ${ }^{5}$, Siti Aqlima Ahmad ${ }^{5}$ Ahmad, S.A.

${ }^{1}$ Center For Biotechnology Research, Bayero University, PMB 3011 Kano, Nigeria

${ }^{2}$ Department of Biochemistry, Faculty of Science, Bauchi State University, Gadau, Nigeria

${ }^{3}$ Department of Microbiology, Faculty of Science, Bauchi State University, Gadau, Nigeria

${ }^{4}$ School of Dental Health Sciences, Shehu Idris College of Health Sciences, Makarfi Kaduna

${ }^{5}$ Department of Biochemistry, Faculty of Biotechnology and Biomolecular Sciences, Universiti Putra Malaysia, 43400

UPM Serdang, Selangor, Malaysia

sibrahim.cbr@buk.edu.ng/+2348034579357

\begin{abstract}
Caffeine is an important naturally occurring compound that can be degraded by bacteria. Excessive caffeine consumption is known to have some adverse problems. Previously, Leifsonia sp. strain SIU capable of degrading caffeine was isolated from agricultural soil. The bacterium was tested for its ability to degrade caffeine as the sole carbon and nitrogen source. The isolate was encapsulated in gellan gum and its ability to degrade caffeine in the presence of heavy metals was determined. Out of the nine heavy metals tested, Copper (Cu), Mercury $(\mathrm{Hg})$, and Silver $(\mathrm{Ag})$ had significant effects on caffeine degradation at $1 \mathrm{mg} / \mathrm{L}$. Therefore, the concentration of these heavy metals was varied from 0 - $1 \mathrm{mg} / \mathrm{L}$ to see at what concentration each metal it has effect. Ag and $\mathrm{Hg}$ showed effect at $0.1 \mathrm{mg} / \mathrm{L}$ with caffeine degradation of 64.05 and $52.17 \%$ respectively, while Cu showed effect at $0.8 \mathrm{mg} / \mathrm{L}$ with caffeine degradation of $64.74 \%$. These bacterium features make it an ultimate means for caffeine bioremediation. This is the first report of effect of heavy metals on caffeine degradation by immobilised Leifsonia sp. strain SIU.
\end{abstract}

Keywords: Caffeine, Degradation, Heavy metals, Immobilisation, Leifsonia sp.

\section{INTRODUCTION}

Caffeine (1,3,7-trimethylxanthine) is a naturally occurring purine alkaloid that is present in many plant species such as tea leaves, cocoa, coffee seeds, yerba mate, colanut, and guarana (Ashihara and Crozier, 2001). Though prolonged caffeine consumption increases alertness and concentration by overcoming fatigue (Smith, 2002; Ibrahim et al., 2014), research on this compound revealed many deleterious effects that it may have on the human body. Prolonged caffeine consumption not only leads to addiction and subsequent withdrawal effects like headaches, nausea and drowsiness (Nehlig, 1999), it also results in many clinical conditions like increase in blood pressure, osteoporosis and cardiac arrhythmia (Lorist and Tops, 2003; Nawrot et al., 2003; Ibrahim et al., 2015a).

Caffeine is one of the major toxic compounds generated by solid wastes in the tea and coffee industries, i.e., coffee pulp, husk and tea waste. In spite of the fact that these wastes are enriched with proteins and carbohydrates, they cannot be used as animal feed because of the presence of caffeine and other toxic compounds (Pandey et al., 2000). Channeling of these wastes to nearby lakes and rivers would have effect on aquatic organisms (Ibrahim et al., 2015b; Gibson et al., 2009). As such, caffeine degradation is paramount in the health and environmental point of view.

Heavy metals are essential as trace elements or trace metals to all living organisms, but excessive concentrations can cause severe toxic effects to living organisms such as human, plants and animals (Poli et al., 2009). The existence of heavy metals at the contamination area is the major limiting factor for bioremediation, as many organisms cannot withstand high concentration of heavy metals thus losing their capacity to degrade the contaminants. The wide spread occurrence of heavy metals in the environment can be due to disposal of waste products (Lasat, 2002). Moreover, it can also be due to such industries that involves metal processing, wood combustion, mineral and coal oil, and also from the use of plant protection (Schinner and Klauser, 2005). In Malaysia, heavy metals enter the environment either from agricultural and industrial activities or human waste (Alkarkhi et al., 2008). Alkarkhi et al., (2008) equally reported that heavy metals were detected in Jejawi and Juru River. In the report, $\mathrm{Pb}, \mathrm{Cd}, \mathrm{As}$, and $\mathrm{Hg}$ contents exceeds the Malaysian standards level. In another report, Ramli and Ang, (2000) reported that ex-mining lands in Perak, and Bidor are contaminated with four heavy metals, $\mathrm{Pb}, \mathrm{Cd}$, As, and $\mathrm{Hg}$. Besides that, $\mathrm{Zn}, \mathrm{Cu}, \mathrm{Ni}$, and $\mathrm{Fe}$ were also detected in $\mathrm{Kg}$. Sungai Berembang (Perlis), Pantai Teluk Air Tawar and Sungai Layar (Kedah) (Yap et al., 2009). This shows that the metals are transported to marine environmental river and through estuaries. This research is aimed at studying the action of heavy metals on caffeine degradation by immobilised Leifsonia sp. strain SIU. 
Bajopas Volume 8 Number 2 December, 2015

Previously, we have isolated a new bacterium that is capable of utilising caffeine as a sole source of carbon and nitrogen and was identified as Leifsonia sp. strain SIU (Ibrahim et al., 2015b). The bacterium was immobilised and tested on the effect of heavy metals. Out of all the heavy metals tested, it shows $\mathrm{Cu}, \mathrm{Hg}$, and $\mathrm{Ag}$ has effect on caffeine degradation. This study was aimed at showing at what concentration do these heavy metals have effect on caffeine degradation by immobilised Leifsonia sp. strain SIU.

\section{MATERIALS AND METHODS}

\section{Chemicals}

Caffeine anhydrous $>99 \%$ was purchased from Sigma, Aldrich USA. Other chemicals used are of analytical grade that were obtained from recognised chemicals suppliers, Fisher (Malaysia) and Merck (Darmstadt, Germany).

\section{Media}

Previously isolated Leifsonia sp. strain SIU was cultured at $30{ }^{\circ} \mathrm{C}$ in sterilised caffeine liquid medium (CLM) containing the following (g/L): $0.4 \quad \mathrm{~K}_{2} \mathrm{HPO}_{4}, 0.2$ $\mathrm{KH}_{2} \mathrm{PO}_{4}, 0.1 \mathrm{NaCl}, 0.1 \mathrm{MgSO}_{4}, 0.01 \mathrm{MnSO}_{4} . \mathrm{H}_{2} \mathrm{O}, 0.01$ $\mathrm{Fe}_{2}\left(\mathrm{SO}_{4}\right)_{3}, 0.01 \mathrm{NaMoO}_{4} .2 \mathrm{H}_{2} \mathrm{O}, 0.4 \mathrm{NH}_{4} \mathrm{Cl}$. The media contains $0.3 \mathrm{~g} / \mathrm{L}$ of caffeine in addition to the above compositions. Carbon sources if any added to the medium were sterilised separately and then mixed to the medium under aseptic conditions. For solid medium, (25 $\mathrm{g} / \mathrm{L})$ agar was added to the caffeine medium. The isolates were maintained and subcultured in the caffeine agar medium.

\section{Cell Immobilisation Protocol}

Cell immobilisation using gellan gum as a gelling component was carried out following the technique described by Ahmad et al., (2012). Briefly, gellan gum $(0.75 \% \mathrm{w} / \mathrm{v})$ was added to $100 \mathrm{~mL}$ deionised water and heated to $75{ }^{\circ} \mathrm{C}$. Then, $\mathrm{CaCl}_{2}(0.06 \% \mathrm{w} / \mathrm{v})$ was added to the mixture and slowly cooled to $45^{\circ} \mathrm{C}$. The $\mathrm{pH}$ of the solution was adjusted to $\mathrm{pH} 7.0$ using $0.1 \mathrm{M}$ $\mathrm{NaOH}$. This phase is called Pregel solution. Leifsonia sp. strain SIU were centrifuged at $7000 \mathrm{rpm}$ for $10 \mathrm{~min}$ at room temperature to obtain the pellet. Wet weight of the resulting bacterial pellet $(3.50 \mathrm{~g})$ was dispersed in the gum mixture and continuously stirred. Beads were formed by using a peristaltic pump by dropping the gum mixture through a modified pipette tip into sunflower-canola oil containing $0.15 \%$ Span 80 as an emulsifier. The uniformly-sized beads were then separated from the oil by transferring them into $\mathrm{CaCl}_{2}$ $0.1 \%(\mathrm{w} / \mathrm{v})$. After $2 \mathrm{~h}$, the beads were repeatedly rinsed with Tween 80 solution $0.1 \%(\mathrm{v} / \mathrm{v})$ to remove the oil phase from the microbeads. Prior to the usage, the beads were kept overnight in distilled water at $4{ }^{\circ} \mathrm{C}$ before being harvested by filtration.

\section{Effect of Heavy Metals}

The effect of some heavy metals on caffeine degradation by immobilised Leifsonia sp. strain SIU was studied. Heavy metals that have effect on caffeine degradation were picked and as such, the final concentration of these metals in the degradation media was varied from $0-1 \mathrm{mg} / \mathrm{L}$. The reaction mixture was incubated in an optimised condition for $24 \mathrm{~h}$ in a rotary shaker at $150 \mathrm{rpm}$. The amount of caffeine degradation was measured using high performance liquid chromatography (HPLC). All the experiments were conducted in triplicates.

\section{Analytical Methods}

Degradation of caffeine was estimated by HPLC (Agilent 1100 series from Agilent technologies, Waldbronn, Germany, Product No. G2170AA) equipment using a ZORBAX $^{\circledR}$ SB-C18 column (USA, Product No. 880975-902, Batch No. B03024) with 10 $\mathrm{mM}$ ammonium phosphate buffer $(\mathrm{pH} 2.5) /$ acetonitrile $(4: 1, v / v)$ as mobile phase (with reference to specifications in the HPLC user manual). Pure caffeine at $2 \mathrm{mg} / \mathrm{mL}$ was used as the standard. Retention time of caffeine was found to be $2.1 \mathrm{~min}$ at a flow rate of 1 $\mathrm{mL} / \mathrm{min}$ and at $30{ }^{\circ} \mathrm{C}$. Detection of caffeine was done at $254 \mathrm{~nm}$ (detector sensitivity: $1 \times 10^{-14}$ absorbance unit) (Ahmad et al., 2015).

The percentage of caffeine degradation was calculated as follows.

Caffeine degradation $(\%)=$

where $a$ is the initial concentration and $b$ is the residual caffeine concentration.

\section{RESULTS AND DISCUSSION \\ Effect of Heavy Metals on Caffeine-degrading Activities by Immobilised Cells}

It was been shown previously that many heavy metals can affect microorganisms even at low concentrations (Kim, 1985). Figure 1 shows the effect of different heavy metals on caffeine degradation by immobilised cells at $1 \mathrm{mg} / \mathrm{L}$ after $24 \mathrm{~h}$ of incubation. From the result obtained for immobilised cells, three out of nine heavy metals tested have inhibitory effect on caffeinedegrading activities. These include $\mathrm{Cu}, \mathrm{Hg}$ and $\mathrm{Ag}$ $(p<0.05)$. Ag gave the highest effect on caffeine degradation, where only $21.33 \%$ was degraded, followed by $\mathrm{Hg}$ (23.45\%) and $\mathrm{Cu}$ (26.14\%) respectively. Other heavy metals such as $\mathrm{Cd}, \mathrm{Zn}, \mathrm{Ni}$, and $\mathrm{Cr}$, showed significant difference on caffeinedegrading activities $(p<0.05)$ with a degradation percentage of $97.74 \% 82.11 \%, 95.35 \%$, and $96.64 \%$ respectively. More so, degradation of As and $\mathrm{Pb}$ showed that there were no significant difference on caffeine-degrading activities $(p>0.05)$ with a degradation percentage of $92.16 \%$, and $92.90 \%$ respectively. Medium without addition of heavy metals showed high caffeine degradation for immobilised cells compared to media with heavy metals.

Heavy metals affect degradation by inhibiting the bacterial growth (Kim, 1985) or the enzymes that play a role in degradation. Heavy metals also affect the membrane structure by disturbing the electron transport chain. Therefore, the presence of heavy metals on immobilised cells was shown to have negative effect on caffeine degradation.

Pollutants and toxic compounds degradation in the environment are mostly due microbial activities as shown in several reports for instance the bioremediation of heavy metals (Shukor et al., 2010), phenol derivatives (Aguayo et al., 2009; Seja'kova et al., 2009), diesel (Sadouk et al., 2009), azo dyes (Gonza'lez-Gutie' rrez et al., 2009; Syed et al., 2009; Revankar and Lele, 2006), and pesticides (Chatterjee et al., 2010). However, the growth of these organisms is inhibited at high concentrations of the toxic compounds which turn to be very toxic, thus limiting the effectiveness of the caffeine biodegradation. 
This result is in accordance with the result obtained by Hong et al., (2007) where heavy metal has a slightly inhibitory effect on dibenzofuran. These toxic compounds also exert their toxic effects by inhibiting caffeine-degrading enzymes or other metabolic enzymes needed for growth (Nies, 1999).

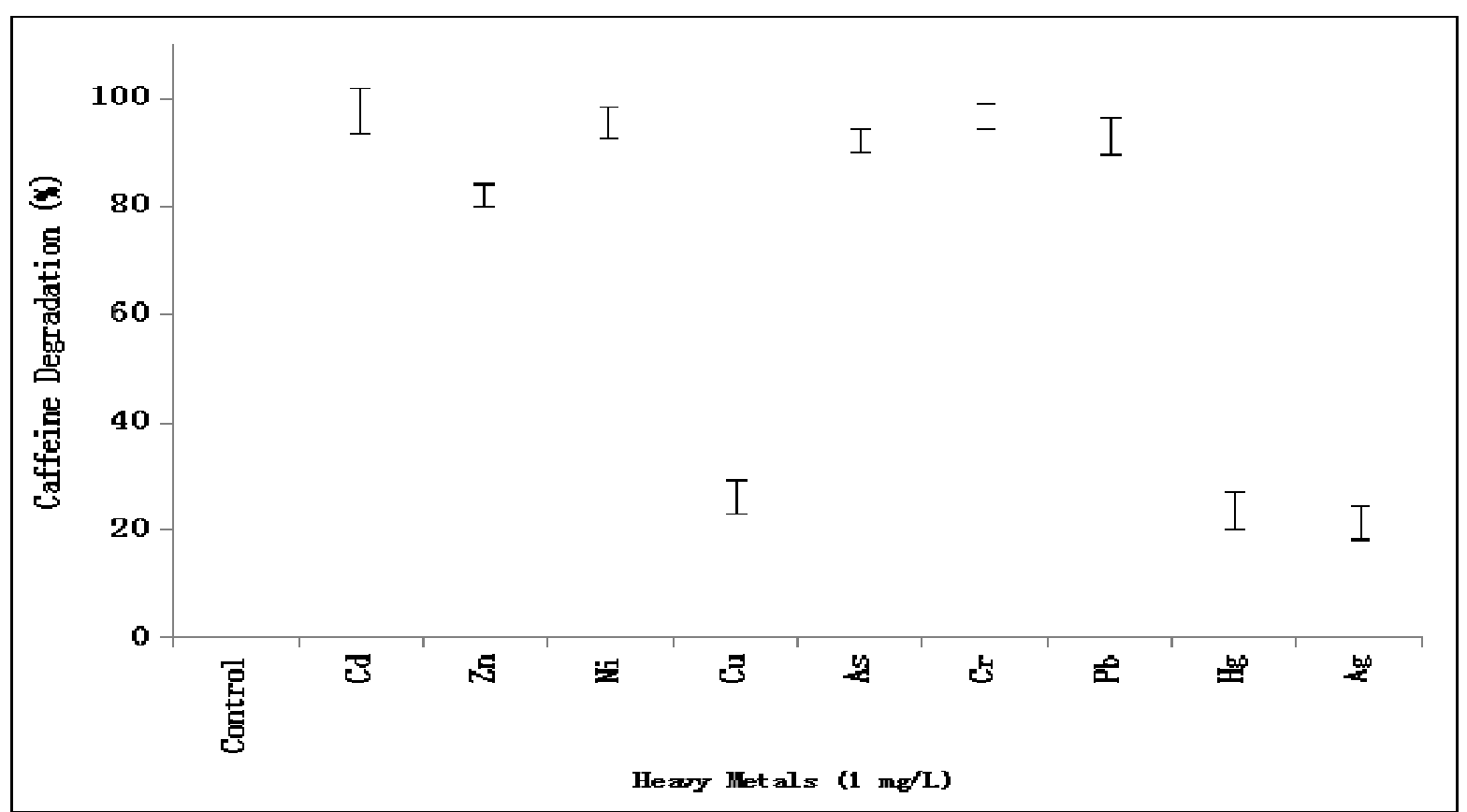

Figure 1. Effect of different heavy metals on caffeine degradation at initial concentration of $0.3 \mathrm{~g} / \mathrm{L}$ by immobilised Leifsonia sp. strain SIU after $24 \mathrm{~h}$ of incubation time. Data represent mean \pm STDEV, $\mathrm{n}=3$.

Effect of Copper on Caffeine-degrading Activities by Immobilised Cells

Copper is an important cofactor in many of the enzymatic processes taking place within the cell. However, $\mathrm{Cu}$ is highly reactive and for that reason it is toxic to the cell in high concentrations and is natural anti-microbial materials (Abushelaibi, 2005). Ancient civilizations exploited the antimicrobial properties of copper long before the concept of microbes became understood in the nineteenth century (Dollwet and Sorenson, 1985). In addition to numerous copper medicinal preparations, it was also observed centuries ago that water contained in copper vessels or transported in copper conveyance systems was of better quality than water contained or transported in other materials. The antimicrobial properties of $\mathrm{Cu}$ are still under active study. Molecular mechanisms responsible for the antibacterial action of copper have been a subject of intensive research. Scientists are also actively indicating the intrinsic efficacies of $\mathrm{Cu}$ alloy touch surfaces to destroy a wide range of microorganisms that threaten public health.

In this study, the effect of $\mathrm{Cu}$ on caffeine degradation was determined from 0 to $1 \mathrm{mg} / \mathrm{L}$. The results (Figure 2) obtained showed that $\mathrm{Cu}$ concentrations from 0.1 to $1 \mathrm{mg} / \mathrm{L}$ affected caffeine-degrading performance ( $p>0.05$ ). However, there was no caffeine degradation inhibition between 0 to $0.5 \mathrm{mg} / \mathrm{L}$. Degradation was observed when the concentration exceeds $0.5 \mathrm{mg} / \mathrm{L}$ $(p<0.05)$. At $0.6,0.7$ and $0.8 \mathrm{mg} / \mathrm{L}$ the degradation was found to be $94.28,92.27$ and $64.73 \%$ respectively while at 0.9 and $1 \mathrm{mg} / \mathrm{L}$ it shows the highest inhibition of 33.95 and $26.25 \%$ respectively. Cu has antimicrobial effects that can inhibit bacterial growth and degradation. 


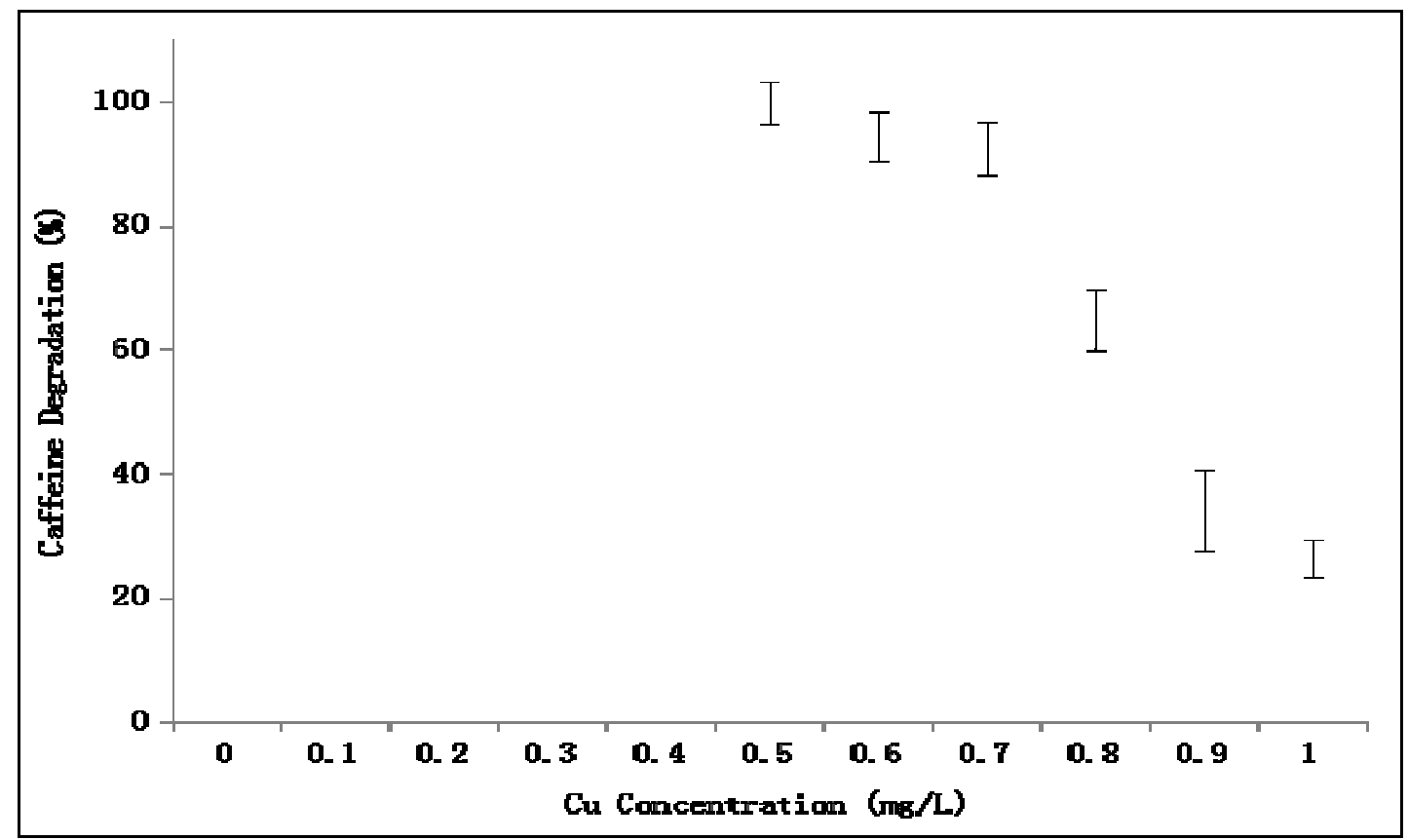

Figure 2. Effect of $\mathrm{Cu}$ on caffeine degradation of immobilised Leifsonia sp. strain SIU. Data represents mean \pm STDEV, $\mathrm{n}=3$.

\section{Effect of Silver on Caffeine-degrading Activities by Immobilised Cells}

Silver $(\mathrm{Ag})$ is used as an antibacterial agent in medical practices as well as in textile fabrics (Atiyeeh et al., 2007). $\mathrm{Ag}$ is found relatively high in concentration in the sludge sample (Sethu et al., 2005), has the potential to prevent bacterial colonisation by its broadspectrum of antimicrobial activity against Gramnegative and Gram-positive bacteria, fungi, protozoa, and some viruses (Tien et al., 2008). According to Malaysian DOE 2004 report, the exported wastes were derived from 36 waste generators and comprised of metal hydroxide sludge containing heavy metals such as $\mathrm{Ag}, \mathrm{Cu}$, and $\mathrm{Ni}(\mathrm{DOE}, 2004)$. Effect of $\mathrm{Ag}$ on caffeine degradation was studied.

In this study, the effect of $\mathrm{Ag}$ on caffeine degradation was determined from 0 to $1 \mathrm{mg} / \mathrm{L}$. The result (Figure 3) obtained showed that $\mathrm{Ag}$ concentrations from 0.1 to $1 \mathrm{mg} / \mathrm{L}$ affected caffeine-degrading performance $(p<0.05)$. Ag can be considered as harmful metal to immobilised Leifsonia sp. strain SIU due to its effects on caffeine degradation at a very low concentration. At $0.1 \mathrm{mg} / \mathrm{L}$ caffeine degradation was $64 \%$ and $30 \%$ at $1.0 \mathrm{mg} / \mathrm{L}$ respectively. It illustrates that $\mathrm{Ag}$ can simply entered immobilised bead due to it high ionisation energy and bead faster than caffeine substance (Milton and Reetha, 2012).

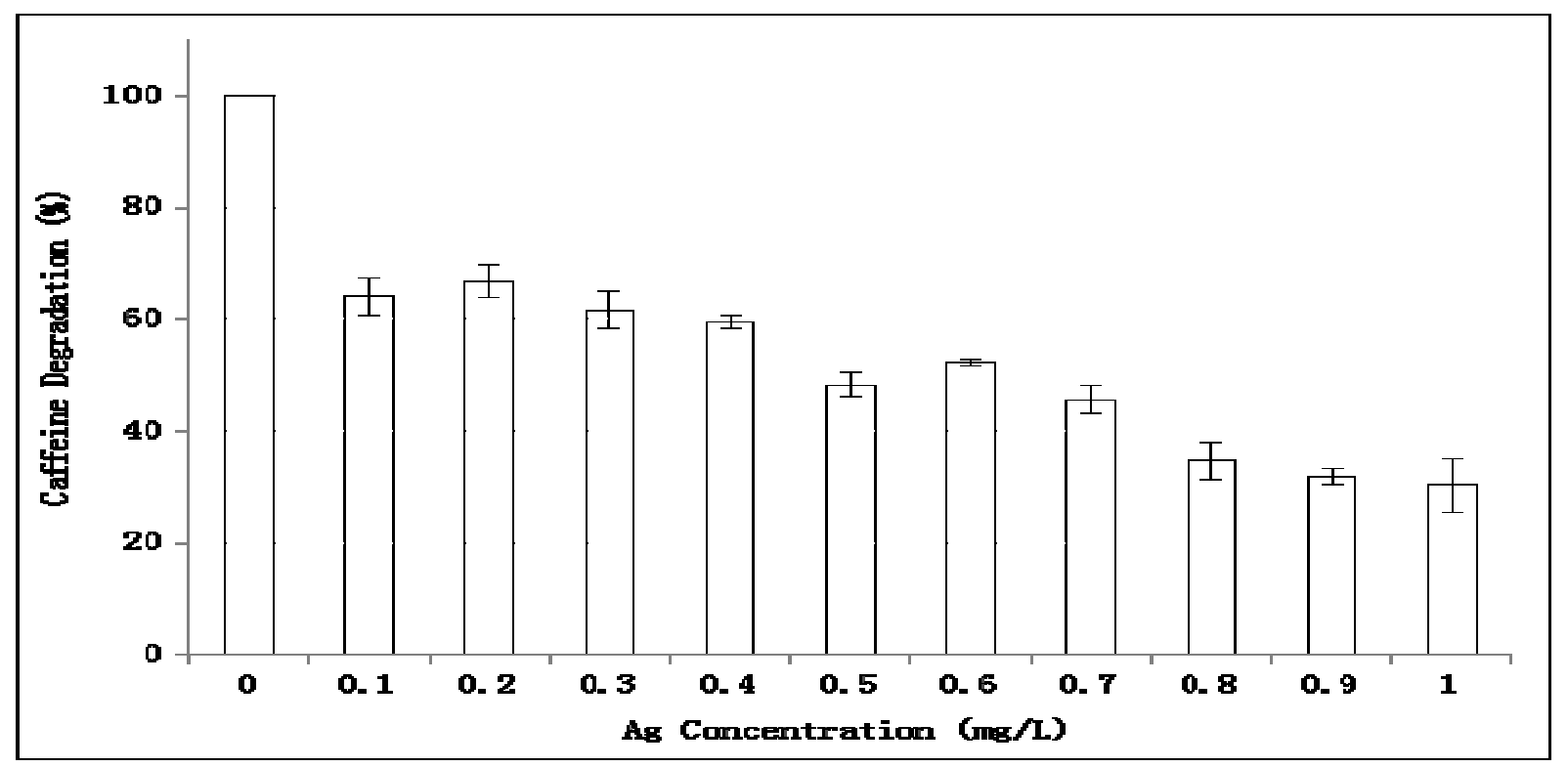

Figure 3. Effect of $\mathrm{Ag}$ on caffeine degradation of immobilised Leifsonia sp. strain SIU. Data represents mean \pm STDEV, $\mathrm{n}=3$. 
Effect of Mercury on Caffeine-degrading Activities by Immobilised Cells

Mercury $(\mathrm{Hg})$ is considered the most toxic nonradioactive metal in the environment and toxic in any form (Abdel-Salam et al., 2010). Asia is one of the major contributors of anthropogenic atmospheric $\mathrm{Hg}$ and serious $\mathrm{Hg}$ pollutions were found in the area influenced by chemical industry, gold mining and $\mathrm{Hg}$ mining (Li et al., 2009). In Malaysia, the main source of $\mathrm{Hg}$ in rivers are from urban and agricultural run-off and effluent from industries sewage treatment plants, domestics discharges, constructions, earthwork and pig farms (DOE, 2002). It appears that, this heavy metal also appears in caffeine-contaminated site. Hence, effect of $\mathrm{Hg}$ on caffeine degradation was studied.
In this study, the effect of $\mathrm{Hg}$ on caffeine degradation was determined from 0 to $1 \mathrm{mg} / \mathrm{L}$. The results (Figure 4) obtained showed that $\mathrm{Hg}$ concentrations from 0.1 to $1 \mathrm{mg} / \mathrm{L}$ affected caffeine-degrading performance. Increasing $\mathrm{Hg}$ concentration to $0.4 \mathrm{mg} / \mathrm{L}$ leads to decrease in caffeine degradation by $27 \%$, which can be classified as detrimental. Radjendirane et al., (1991) reported that $\mathrm{Hg}$ could also inhibit hydroxylases activity like aryl 2,4-dichlorophenol hydroxylase and 3hydroxybenzoate-6-hydroxylase. Analysis of variance showed that there was no significant difference in caffeine degradation between $0.4,0.50 .6$ and 0.7 $\mathrm{mg} / \mathrm{L}(\mathrm{p}>0.05)$ but the remaining concentration shows there was a significant difference between them $(p<0.05)$.

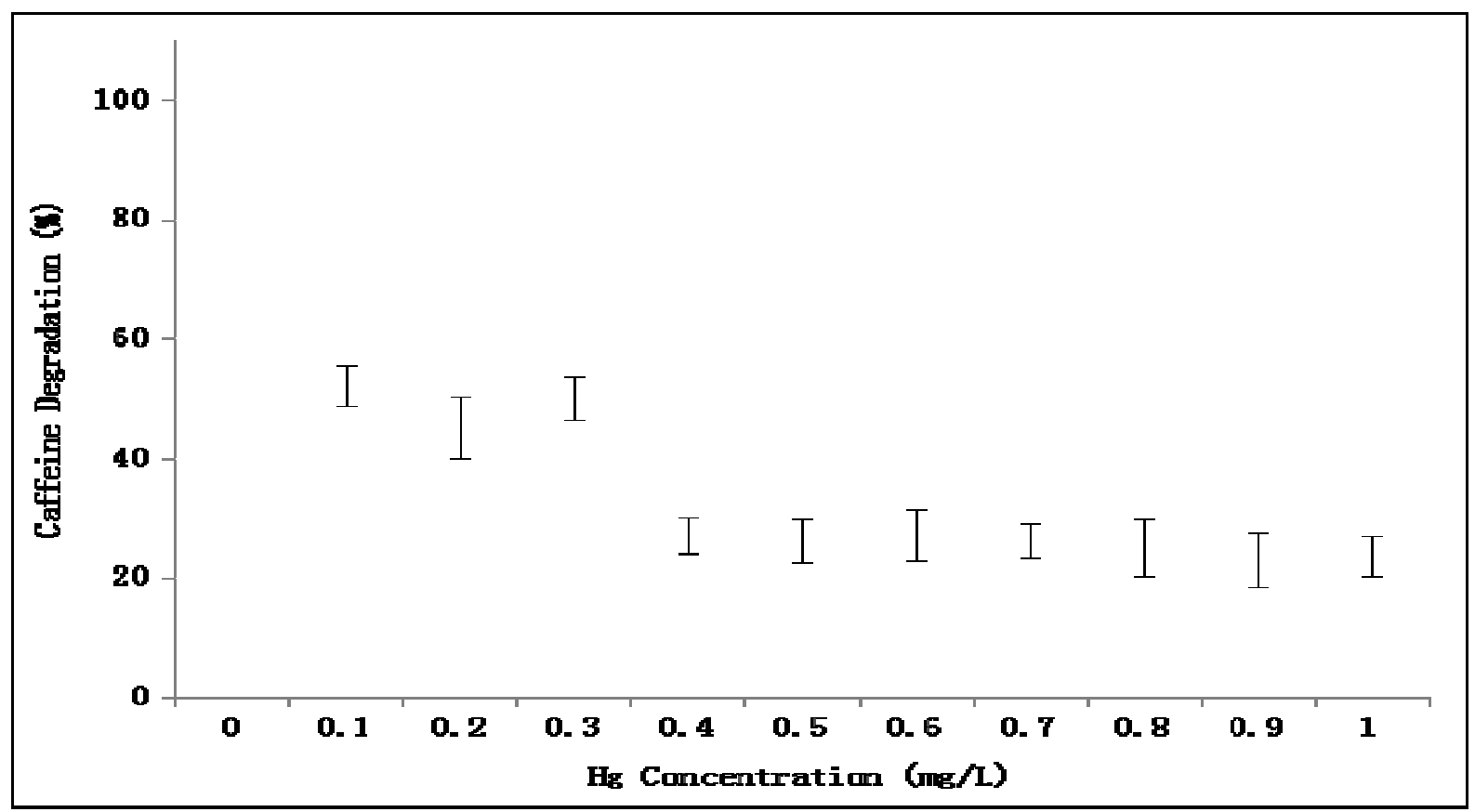

Figure 4. Effect of $\mathrm{Hg}$ on caffeine degradation of immobilised Leifsonia sp. strain SIU. Data represents mean \pm STDEV, $\mathrm{n}=3$.

Heavy metals are toxic to most microorganisms at specific concentrations and often cause serious upsets in biological waste treatment plants. The mechanism by which these heavy metals affect the microorganisms to degrade caffeine is not clear. Nevertheless, it has been suggested that heavy metals block the enzyme systems or interfere with some essential cellular metabolite of bacteria (Majid, 2010). Heavy metals inhibit microorganisms by blocking essential functional groups or interfering with essential metal ions incorporation of biological molecules. In some cases microorganisms are resistant to some heavy metals through different possible mechanisms (Martins et al., 2008).

The inhibition of caffeine demethylase enzyme for caffeine degradation follows non-competitive inhibition model, which is an inhibition where by the inhibitor (heavy metals) forms complex at a point other than the active site, as such it alters the structure of the enzyme in such a way that the substrate may get attached to the active site but products are not formed. The reaction goes on decreasing as more and more inhibitors contact the enzyme till saturation is reached.

\section{Conclusion}

The effect of heavy metals on caffeine biodegradation was studied using a newly isolated bacterium immobilised Leifsonia sp. strain SIU. The isolate was encapsulated in gellan gum and its ability to degrade caffeine in the presence of heavy metals was determined. Out of the nine heavy metals tested, Copper $(\mathrm{Cu})$, Mercury $(\mathrm{Hg})$, and Silver $(\mathrm{Ag})$ have effects on caffeine degradation using $1 \mathrm{mg} / \mathrm{L}$ of the heavy metals. $\mathrm{Ag}$ and $\mathrm{Hg}$ showed significant effect at $0.1 \mathrm{mg} / \mathrm{L}$ with caffeine degradation of 64.05 and $52.17 \%$ respectively, while $\mathrm{Cu}$ showed effect at 0.8 $\mathrm{mg} / \mathrm{L}$ with caffeine degradation of $64.74 \%$. The present information regarding the effect of heavy metals on caffeine degradation as an effective degrader can be useful to the real state where degradation is essential in caffeine contaminated areas. 


\section{Conflict of Interests}

The authors declare that there is no conflict of interests regarding the publication of this paper.

\section{REFERENCES}

Abdel-Salam, A. M., Al-Dekheil, A., Babkr, A., Farahna, M., and Mousa, H. M. (2010). High fiber probiotic fermented mares milk reduces the toxic effects of mercury in rats. N.Am. J. Med. Sci., 2(12), 569-575.

Aguayo, J., Barra, R., Becerra, J., and Martı'nez, M. (2009). Degradation of 2, 4, 6tribromophenol and 2, 4, 6-Abushelaibi, A. (2005). Antimicrobial Effects of Copper and Brass Ions on the Growth of Listeria Monocytogenes at Different Temperatures, $\mathrm{pH}$ and Nutrients pp. 1-113.

trichlorophenol by aerobic heterotrophic bacteria present in psychrophilic lakes. World $\mathrm{J}$. Microbiol. Biotechnol., 25, 553-560.

Ahmad, S. A., Ibrahim, S., Shukor, M. Y., Johari, W. L. W. J., Rahman, N. A., and Syed, M. A. S. (2015). Biodegradation kinetics of caffeine by Leifsonia sp. strain SIU. J. Chem. Pharm. Sci., 8(2), 312-316.

Ahmad, S. A., Shamaan, N. A., Arif, N. M., Koon, G. B., Shukor, M. Y. A., and Syed, M. A. (2012). Enhanced phenol degradation by immobilized Acinetobacter sp. strain AQ5NOL 1. World J. Microbiol. Biotechnol., 28(1), 347-52.

Alkarkhi, A. F. M., Ahmad, A., Norli, I., and Easa, A. M. (2008). Multivariate analysis of heavy metals concentrations in river estuary. Environ. Monit. Assess., 143(1-3), 179-186.

Atiyeeh, B. S., Costagliola, M., Hayek, S. N., and Dibo, S. A. (2007). Effects of silver on burn wound infection control and healing: Review of the literature. Burns, 33(2), 139-148.

Chatterjee, S., Das, S. K., Chakravarty, R., Chakrabarti, A., Ghosh, S., and Guha, A. K. (2010). Interaction of malathion, an organophosphorus pesticide with Rhizopus oryzae biomass. J. Hazard. Mater., 174(1-3), 47-53.

Department of Environment. (2002). Malaysian Environmental Quality report 2002. Department of Environment, Ministry of Natural Resources and Environment Malaysia. Publication section Strategic Communication Division, Department of Environment Malaysia. pp. 65.

Department of Environment. (2004). Malaysian Environmental Quality report 2004. Department of Environment, Ministry of Natural Resources and Environment Malaysia. Publication section Strategic Communication Division, Department of Environment Malaysia. pp. 60.

Dollwet, H., and Sorenson, J. R. J. (1985). Historic uses of copper compounds in medicine. $J$. Trace Elem. Med. Biol., 2, 80-87.Gibson, A.

\section{Acknowledgments}

This research was supported by the Ministry of Science, Technology and Innovation, Malaysia (MOSTI) under the Project Number 02-01-04-SF1473.

M., Morgan, R. M., and Nikitin, A. G. (2009). The effect of caffeine on the bacterial populations in a freshwater aquarium system. Student Summer Scholars. Paper 31.

Gonza'lez-Gutie'rrez, L. V., Gonza'lez-Alatorre, G., and Escamilla-Silva, E. M. (2009). Proposed pathways for the reduction of a reactive azo dye in an anaerobic fixed bed reactor. World J. Microbiol. Biotechnol., 25, 415-426.

Hong, H. B., Nam, I. H., Kim, Y. M., Chang, Y. S., and Schmidt, S. (2007). Effect of heavy metals on biodegradation of dibenzofuran in liquid medium. J. Hazard. Mater., 140(1-2), 145148

Ibrahim, S., Shukor, M. Y., Khalil, K. A., Helmi, M. I. E., Syed, M. A., and Ahmad, S. A. (2015a). Application of Response Surface Methodology for optimising caffeinedegrading parameters by Leifsonia sp. strain SIU. J. Environ. Biol., 36(5), 1215-1221.

Ibrahim, S., Shukor, M. Y., Syed, M. A., Wan Johari, W. L., and Ahmad, S. A. (2015b). Characterisation and growth kinetics studies of caffeine-degrading bacterium Leifsonia sp. strain SIU. Ann. Microbiol., 1-10.

Ibrahim, S., Shukor, M. Y., Syed, M. A., Ab Rahman, N. A., Khalil, K. A., Khalid, A., and Ahmad, S. A. (2014). Bacterial Degradation of Caffeine: A Review. Asian J. Plant Biol., 2(1), 24-33.

Kim, S. J. (1985). Effect of heavy metals on natural populations of bacteria from surface microlayers and susurface water. Mar. Ecol. Prog. Ser., 26, 203-206.

Lasat, M. M. (2002). Phytoextraction of toxic metals: A review of biological mechanisms. $J$. Envionmental Qual., 31, 109-120.

Lorist, M. M., and Tops, M. (2003). Caffeine, fatigue, and cognition. Brain and Cognition, 53, 8294.

Majid, S. (2010). Experimental studies on effect of Heavy Metals presence in Industrial Wastewater on Biological Treatment. Int. J. Environ. Sci., 1(4), 666-676.

Martins, S. P. D. O., Almeida, N. F. De, and Gomes, S. L. F. (2008). Application of a bacterial extracellular polymeric substance in heavy metal adsorption in a co-contaminated aqueous system. Brazilian J. Microbiol., 39, 780-786.

Milton, J. D., \& Reetha, D. (2012). Removal of heavy metals using bacteria isolated from lignite mining environment. Int. J. Recent Sci. Res., 3(12), 1071-1078. 


\section{Bajopas Volume 8 Number 2 December, 2015}

Nawrot, P., Jordan, S., Eastwood, J., Rotstein, J., Hugenholtz, A, and Feeley, M. (2003). Effects of caffeine on human health. Food Addit. Contam., 20(1), 1-30.

Nehlig, A. (1999). Are we dependent upon coffee and caffeine? A review on human and animal data. Neurosci. Biobehav., 23(4), 563-576.

Nies, D. H. (1999). Microbial heavy-metal resistance. Appl. Microbiol. Biotechnol., 51(6), 730-750.

Pandey, A., Soccol, C. R., Nigam, P., Brand, D., Mohan, R., and Roussos, S. (2000). Biotechnological potential of coffee pulp and coffee husk for bioprocesses. Biochem. Eng. J., 6(2), 153162.

Poli, A., Salerno, A., Laezza, G., Dumontet, S., and Nicolaus, B. (2009). Heavy metal resistance of some thermophiles: potential use of aamylase from Anoxybacillus amylolyticus as a microbial enzymatic bioassay. Res. Microbiol., 160(2), 99-106.

Radjendirane, V., Bhat, M. A., and Vaidyanathan, C. S. (1991). Affinity purification and characterization of 2,4-dichlorophenol hydroxylase from Pseudomonas cepacia. Arch. Biochem. bioprocess, 288(1), 169176.

Ramli, M. O., and Ang, L. H. (2000). The occurrence of some important potentially toxic trace elements in an ex-mining land located in Bidor, Perak. In proceedings of Malaysian Science and Technology Congress 1999. 810th November, 2000. At Hilton Kuching, Serawak pp. 120-127.

Revankar, M. S., and Lele, S. S. (2006). Increased production of extracellular laccase by the white rot fungus Coriolus versicolor MTCC 138. World J. Microbiol. Biotechnol., 22, 921926.

Sadouk, Z., Tazerouti, A., and Hacene, H. (2009). Biodegradation of diesel oil and production of fatty acid esters by a newly isolated Pseudomonas citronellolis KHA. World $\mathrm{J}$. Microbiol. Biotechnol., 25, 65-70.

Schinner, F., and Klauser, T. (2005). Feasibility studies for microbial remediation of metals contaminated soil. In: R. Margesin and F. Schinner, Editors, Manual for Soil Analysis.

Seja 'kova, Z., Dercova', K., and To'thova', L. (2009). Biodegradation and ecotoxicity of soil contaminated by pentachlorophenol applying bioaugmentation and addition of sorbents. World J. Microbiol. Biotechnol., 25, 243-252.

Sethu, V., Aziz, A. R., and Aroua, M. K. (2005). Selective recovery of aluminium and silver from electroplating wastes. In The AEESEAP International Conference 2005, June 7-8, 2005, Kuala Lumpur Malaysia.

Shukor, M. Y., Ahmad, S. A., Nadzir, M. M. M., Abdullah, M. P., Shamaan, N. A., and Syed, M. A. (2010). Molybdate reduction by Pseudomonas sp. strain DRY2. J. Appl. Microbiol., 108(6), 2050-2058.
Smith, A. (2002). Effects of caffeine on human behavior. Food Chem. Toxicol., 40(9), 124355.

Syed, M. A., Sim, H. K., Khalid, A., and Shukor, M. Y. (2009). A simple method to screen for azodye-degrading bacteria. J. Environ. Biol., 30(1), 89-92.

Tien, D. C., Tseng, K. H., Liao, C. Y., and Tsung, T. T. (2008). Colloidal silver fabrication using the spark discharge system and its antimicrobial effect on Staphylcoccus aureus. Med. Eng. Phys., 30, 948-952.

Yap, C. K., Razeff, S. M. R., Edward, F. B., and Tan, S. G. (2009). Heavy metals concentrations ( $\mathrm{Cu}$, $\mathrm{Fe}, \mathrm{Ni}$ and $\mathrm{Zn}$ ) in the the clam, Glauconome virens, collected from the northern intertidal areas of peninsular Malaysia. Malaysian Appl. Biol., 38(1), 29-35. 